\title{
EFFECT OF IMMERSION TIME OF SHALLOT EXTRACT AND ATONICON SEED GERMINATION OF SHALLOT
}

\author{
Bahrudin $^{1)}$, Muhammad Ansar ${ }^{1)}$ dan Abdul Rahim Thaha ${ }^{1)}$ \\ ${ }^{1)}$ Study Program of Agrotechnology Faculty of Agriculture, Tadulako University, Palu Email : apasigai@ yahoo.com
}

\begin{abstract}
The need for raw materials of fried onions derived from 'lembah palu Shallot tubers variety is high enough and can not be fulfilled, because the productivity is still low. This study aimed to find the type of plant growth regulator substances (PGR) with a long period of proper immersion to improve the germination of Shallot tuber. The research was conducted on Mei until June 2017 in Bulupontou Village, Sigi Regency. The study used two factorial Randomized Block Design (RBD). First factor of type RGS: (Z1) onion extract $100 \mathrm{~g} / \mathrm{l}$ water, and (Z2) atonic $5 \mathrm{ml} / \mathrm{l}$ water. The second factor was long seed immersion in PGR: (T1)=30 min; (T2)=60 minutes; (T3)=90 minutes, and $(\mathrm{T} 4)=120$ minutes. Each treatment was represented 20 plants and repeated 3 times, so it was used 480 plants. The results showed that (i) red onion tubers soaked with Shallot extract $100 \mathrm{~g} /$ liter of water for 30-90 minutes yielded 100\% Germinations, and tubers soaked in red onion extract for 30 minutes resulted in germination rate 31.3\%/etmal, (ii) the type of growth regulator of shallot extract and atonic (PGR) effect was not significant on the germination of shallot; and (iii) the 30 minute long growth regulator immersion produced the highest hypothetical vigor index.
\end{abstract}

Keywords: Atonic, Plant growth regulator substances, Shallot extract.

\section{INTRODUCTION}

Fried onion industry in Central Sulawesi, especially in the City, has been growing since the last five years. For fried onion industry business, the raw material for varieties of red onions is 'lembah palu'. With the business growing of fried onion industry, the need of fried onion raw materials derived from the varieties of shallot tubers in the "lembah palu" is quite high and until now it has not been able to be fulfilled continuously, because the productivity is still low. The average productivity of shallot in the 'lembah palu' at the farm level is only around 4-5 t / ha, while the potential yield can reach $9.7 \mathrm{t} /$ ha (Pasigai et al., 2016). 'lembah palu' red onion is cultivated in Palu Valley area which covers the area of Palu City, as well as parts of the Sigi and Donggala Regency, where the location is generally located at an altitude of less than $400 \mathrm{~m}$ asl.

The main contributing factoris the low productivity of the 'lembah palu' due to the application of cultivation technology that is not in accordance with the Standard Operating Procedure (SOP) technology for the 'lembah palu' cultivation shallot, especially those related to planting material or seedlings that have not met the standards (Muhammad-Anshar et al., 2015). Seed is an input factor that determines plant productivity in addition to environmental and technical management factors. The success rate of cultivating a plant is approximately $40 \%$ determined by the quality of the seed.

The source of the seed used by most red onion farmers in Lembah Palu is from their yield which is deliberately stored as a source of seed for the next planting season. The shallot tubers which are intended as these are the results of the selection of small-sized tubers and the remnants of the tubers sold to the fried onion industry. The size of the seed is very influential on growth, yield components and crop yield, including shallot. Small shallot seed has weaknesses so they provide low growth and low tuber yield. 
This is in accordance with the results of Masna's research (2017) that small tubers ( $<2.9 \mathrm{~g} /$ tuber) produced the lowest growth and yield of shallot tubers in the "lembah palu" variety, while medium-large tubers (> $3 \mathrm{~g} /$ tuber) produced more leaves and tillers, total leaf area and greater total dry weight per plant and longer tubers, more tubers per clump and higher fresh tubers per hectare. The low growth and yield of shallot that used seed from small bulbs, due to the content of food reserves and growth regulators in relatively low seedlings (photohormones) that cannot support good germination and plant vigor, and further affect plant growth and productivity the shallot. To increase plant growth hormones, external hormones can be given through immersion in substances regulating herbs, both natural and synthetic. As stated by Kusumo (1990) that one way to treat using PGR is by immersion the seeds. One of the plants that can be used as a natural growth regulator is onion (Allium cepa L.). because onion has a growth hormone in the form of hormones auxin and gibberellin, so it can spur the growth of seeds (Marfirani, 2014). The results of the Mayasari et al. (2012) found that at the concentration of shallot extract $18 \%-20 \%$ showed the best growth in the parameters of the number of shoots, number of leaves, leaf area and number of roots; whereas synthetic growth regulators that are widely traded today have functions similar to fitohormones, one of which is atonic. Atonik contains 2.4 dinitrophenol sodium aconitrophenol, IBA $(0.057 \%)$ and sodium 5 nitrogulacol which can increase plant growth, because atonics are quickly absorbed by cells, thereby accelerating germination and rooting, but if the concentration is excessive it can inhibit growth.

This research was aimed to find the type of plant growth regulator substance (PGR) with the duration of proper immersiom to fix the germination, vigor and growth of red onion tuber especially from seed with small shallot size.

\section{RESEARCH METHOD}

The study was conducted in May to June 2017 in Bulupontou Jaya Hamlet, Sigi-
Biromaru Sigi Regency. The study used a Randomized Block Design (RBD) of two factorials. The first factor was the type of Plant Growth Regulation Substance (PGR) consisting of: (Z1) natural PGR from shallot extract as much as $100 \mathrm{~g} / 1$ water, and (Z2) synthetic PGR with the name atonic product as much as $5 \mathrm{ml} / 1$ water. The second factor was the duration of seed immersion in PGR: consisting of: $(\mathrm{T} 1)=30$ minutes; $(\mathrm{T} 2)=60$ minutes; $(\mathrm{T} 3)=90$ minutes, and $(\mathrm{T} 4)=120$ minutes. Each treatment was represented by 20 plants and repeated 3 times, so that all 480 plants were used. The parameters observed included vigor and seed viability including: (i) germination, (ii) germination time, (iii) germination rate, (iv) fresh weight and plant dry weight and (v) hypothetical vigor index, according to Sajad (1997) Data from observation were analyzed using analysis of variance (ANOVA). The treatment that had a markedly different response was continued with the HSD Test $\alpha=0.05$ (Gomez \& Gomez, 1995).

The experiment was carried out using a polybag with width $\mathrm{x}$ length $\mathrm{x}$ thick $(10 / 5 \times 15 \times 0.055)$ of 500 sheets (for treatment and reserve plants). Planting media was a mixture of soil and bokashi goat manure with a ratio of 2: 1. Each polybag was planted with one tuber which had been soaked in a function solution for about 10-15 minutes.

Plant maintenance consisted of giving water using sprinkles 1-2 times a day, depending on the weather. Fertilization was carried out by giving $1 \mathrm{~g}$ of urea/plant which was done when the tuber has germinated which is on the 5th day after planting. Pest control (leaf caterpillar) is carried out physically by taking and killing pests found on the red onions. Diseases that attacked plants were controlled using a fungicide (Dithane M-45) which was sprayed if there were symptoms of an attack.

\section{RESULTS AND DISCUSSION}

Germination Power. The results of the variance analysis showed that there were 
real interactions between the types of growth regulating substances and the immersion time of the tubers to the varieties of 'lembah palu' shallot.

Based on the test results of $\alpha 0,05$ HSD, it was found that the type of growth regulator and different immersion time gave an average of $100 \%$ germination, except atonic growth regulators with 90 minutes immersion time (Z2T3) resulting in lower Germination power and significantly different from interactions other treatment. This showed that to increase the ability of germinating tubers, additional growth regulators were needed from outside of the plant (external hormones). Plant growth regulator substance of shallot tuber extract which were external hormones with allicin compounds content, wherein allicin was compounded with thiamin to form allithiamin which had biological activities, namely the ability to stimulate cell growth and increase energy for germination (Erlianti, 1999).

Germination Time. The time of germination of shallot was not influenced by the interaction of type and immersion time of growth regulators; as well as single type factors and immersion time for growth regulators. This can be caused by the germination time of shallot seedlings that was strongly influenced by tuber harvesting age and tuber storage time after harvest, so that the role of growth regulator given with different immersion times had not shown significant differences in the time of germinating 'lembah palu' seedlings. The results of the study by Muhammad-Ansar et al. (2015) showed that the harvest age of 65-70 days after planting with a shelf life of 30-40 days after harvest produced vigor and viability of shallot tubers of 'lembah palu' variety, with the highest germination $(100 \%)$, on the contrary the harvest age of 75 days after planting had a 6-17\% Germination power decline if stored for 50-60 days after harvest; and the time to grow and the speed of germination was better than other treatments.

Germination Speed. The results of the variance analysis showed that there was a real interaction between the type of plant growth regulator and the duration of immersion tubers to the speed of germination of "lembah palu" shallot tubers variety'. The germination rate was obtained highest on the interaction of shallot extract treatment with 30 minutes immersion (Z1T1), but not significantly different from other treatments, except with PGR treatment interaction of shallot extract with 120 minutes immersion time (Z1T4) and atonic PGR with immersion time 60 minutes (Z2T2) obtained lower germination speed (Table 1). This showed that the addition of external growth hormone in the right amount, because the nature of the hormone grows was to help stimulate cell division in lower concentrations and vice versa in higher concentrations can inhibit plant cell growth. As stated by Salisbury (1995) that plant hormones are plant organic compounds which in low concentrations affect physiological processes. These physiological processes are mainly about the process of growth, differentiation and development of plants. Onion tuber extract which is one source of external growth hormone which contains a lot of natural auxin and affects germination and plant growth. The auxin content contained in shallot extract influences the metabolic processes of plants. Each plant has a hormone to stimulate germination, but the hormones in the seeds are small in number so that it is added so that the seed growth will be faster and better. The concentration of growth regulator (PGR) in the treatment will affect the amount and speed of absorption that occurs in the seeds, so that it will affect the germination, germination rate, and seed fertility (Kusumo, 1990).

Hypothetic Vigor Index. The interaction of type and duration of immersion of growth regulator substance and the single factor type of growth regulator did not significantly influence the hypothetical shallot vigor index, but the single immersion factor of growth regulator substance significantly affected the 'lembah palu' shallot tuber vigor index. The hypothetical vigor index was obtained higher (4.52) with PGR 30 minutes 
immersion time and significantly different from the 90 minute immersion time, but not significantly different from the 60 and 120 minute immersion times (Table 2).

This showed that the immersion time of tubers in PGR can cause hormone levels in the tubers vary, where there was a tendency that longer immersion will increase the hormone levels contained in the tuber, so that it can affect inhibiting cell division. As stated by Hartmann et al (1997) that growth regulators are hormones that can play a role in spurring plant growth, which in the right concentration can stimulate cell division and elongation, but if in high concentrations it can inhibit cell growth. Growth regulator substances, both in the form of natural auxin (shallot extract) and synthesis (atonic) in the right amount can play a role in the process of cell elongation, stimulating root growth, inhibiting the growth of lateral shoot, preventing the absence of leaves and fruit.

The Number of Leaves. The interaction of type and duration of immersion of growth regulators and the single factor type of growth regulator did not significantly affect the number of shallot leaves, but the long factor of immersion in growth regulators significantly affected the number of 'lembah palu' shallot. The number of leaves was obtained more (12.50 strands) by PGR immersion for 30 minutes and significantly different from the duration of 90 minutes immersion, but not significantly different from the duration of 60 and 120 minutes immersion (Table 2). This is because auxin and giberellin hormone contained in growth regulators shallot extract can play a role in spurring germination, root growth and stimulating the growth of leaves or stems. As Siswanto (2010) found that the administration of shallot extract can increase the growth of long pepper seeds, as a result of the influence of auxin contained in shallot extract. Giberelin as one of the growth hormones that has a function, among others, increasing cell division and enrlaging cell in the form of extending plant segments, enlarging the leaf area of various types of plants, enlarging flowers, fruit and affecting stem duration (Heddy, 1989).

Root Dry Weight. The interaction of type and duration of immersion of growth regulator substance as well as the single factor type of growth regulator and immersion time of growth regulator did not significantly affect the dry weight of the 'lembah palur' root, but in some previous studies it was found that shallot extract could be a natural growth regulatoragent which contains auxin hormone to stimulate root growth in plant cuttings. The addition of exogenous auxin will increase the content of endogenous auxin in cutting tissue so that it can initiate cells to grow and develop which will then differentiate to form organs such as roots. The use of shallot extract as one of the growth regulators has been carried out on several types of plantand it was found that PGR which played an important role in the root growth process was PGR from a class of auxin which was also found in shallot extract. Auxin hormone in shallot can increase the cell elongation process, in this case of root cell. According to Sasmitamihardja (1996), to accelerate and maximize growth, growth regulators were needed in the form of auxin which spurs root development. This can be understood given that the function of auxin which affects physiological processes such as membrane permeability, encourages cell enlargement in the stem, accelerates the enlargement of root cell, and increase the number of roots (Abidin, 1990).

Leaf Dry Weight. The interaction of type and duration of immersion of plant growth regulator and the single factor type of growth regulator did not significantly affect the dry weight of shallot leaves, but the single factor of immersion of growth regulators significantly affected the dry weight of the "lembah palu" shallot. The leaf dry weight was obtained higher $(0.24$ gram/plant) with PGR immersion for 30 minutes and significantly different from the 90 minute immersion time, but not significantly different from the 60 and 120 
minute immersion times (Table 2). These results indicated that the immersrion time of PGR was more influential on plant growth compared to the type of PGR (onion extract and atonic). It was because the hormones contained in each PGR onion and atonic consisted of auxin and giberellin which influence plant growth. In shallot extract contained auxin hormone which can stimulate root growth in plant cutting, while the gibberelin hormone will stimulate growth in the leaves and the stem (Marfirani, 2014).

Table 1. The Average Germination and Speed of Germination of 'Lembah Palu' Shallot in The Type and Immersion Duration of Growth Regulators.

\begin{tabular}{ccl}
\hline Treatment & $\begin{array}{c}\text { Germination Power } \\
(\%)\end{array}$ & $\begin{array}{c}\text { Germination Speed } \\
\text { (\%/etmal) }\end{array}$ \\
\hline Z1T1 & $100,00 \mathrm{a}$ & $31,31 \mathrm{a}$ \\
Z1T2 & $100,00 \mathrm{a}$ & $28,58 \mathrm{ab}$ \\
Z1T3 & $100,00 \mathrm{a}$ & $15,79 \mathrm{ab}$ \\
Z1T4 & $100,00 \mathrm{a}$ & $14,18 \mathrm{~b}$ \\
Z2T1 & $100,00 \mathrm{a}$ & $18,52 \mathrm{ab}$ \\
Z2T2 & $100,00 \mathrm{a}$ & $13,84 \mathrm{~b}$ \\
Z2T3 & $96,67 \mathrm{~b}$ & $21,42 \mathrm{ab}$ \\
Z2T4 & $100,00 \mathrm{a}$ & $15,12 \mathrm{ab}$ \\
\hline HSD $\alpha 0,05$ & 2,94 & 16,943 \\
\hline
\end{tabular}

Description: The average number in the column followed by the same letter was not significantly different from the HSD Test of $\alpha 0,05$.

Table 2. The Average of Hypothetic Vigor Index, The Number of Leaves, and Dry Weight of Shallot of The Lenght of Tuber Immersion.

\begin{tabular}{cccc}
\hline $\begin{array}{c}\text { The lenght of immersion } \\
\text { (minute) }\end{array}$ & $\begin{array}{c}\text { Hypothetic Vigor } \\
\text { Index }\end{array}$ & $\begin{array}{c}\text { The Number of Leaves } \\
\text { (Strand) }\end{array}$ & $\begin{array}{c}\text { Try Weight of } \\
\text { Leave } \\
\text { (gram) }\end{array}$ \\
\hline $\mathrm{T} 1=30$ & $4,52 \mathrm{a}$ & $12,50 \mathrm{a}$ & $0,24 \mathrm{a}$ \\
$\mathrm{T} 2=60$ & $4,03 \mathrm{ab}$ & $10,71 \mathrm{ab}$ & $0,21 \mathrm{ab}$ \\
$\mathrm{T} 3=90$ & $3,78 \mathrm{~b}$ & $9,00 \mathrm{~b}$ & $0,19 \mathrm{~b}$ \\
$\mathrm{~T} 4=120$ & $3,99 \mathrm{ab}$ & $10,83 \mathrm{ab}$ & $0,20 \mathrm{ab}$ \\
\hline HSD $\alpha 0,05$ & 0,56 & 2,86 & 0,04 \\
\hline
\end{tabular}

Description : The average number in the column followed by the same letter was not significantly different from the HSD $\alpha 0.05$ test

Table 3. Average Dry Weight of Shallot Tuber with Different Type and Immersion Duration.

\begin{tabular}{cccccccc}
\hline \multirow{2}{*}{$\begin{array}{c}\text { Plant Growth } \\
\text { Regulator Substance }\end{array}$} & \multicolumn{9}{c}{ The Duration of Atonic Immersion } & (minute) & & \multirow{2}{*}{ HSD } \\
\cline { 2 - 5 } & 30 & 60 & 90 & 120 & & $\alpha 0,05$ \\
\hline Red onion extract & 0,56 & 0,24 & 0,17 & 0,18 & $0,29 \mathrm{a}$ & \\
Atonic & 0,69 & 0,56 & 0,28 & 0,34 & $0,47 \mathrm{~b}$ & 0,18 \\
\hline Average & $0,63 \mathrm{a}$ & $0,40 \mathrm{ab}$ & $0,23 \mathrm{~b}$ & $0,26 \mathrm{~b}$ & & \\
\hline HSD $\alpha 0,05$ & \multicolumn{8}{c}{0,34} \\
\hline
\end{tabular}

Description : The average number in the column followed by the same letter was not significantly different from the HSD $\alpha 0.05$ test 
Table 4. Average Dry Weight of Shallot Tuber With Different Type and Immersion Duration

\begin{tabular}{|c|c|c|c|c|c|c|}
\hline \multirow{2}{*}{$\begin{array}{c}\text { Plant Growth Regulator } \\
\text { Substance }\end{array}$} & \multicolumn{4}{|c|}{ The Duration of Atonic Immersion (minute) } & \multirow[b]{2}{*}{ average } & \multirow{2}{*}{$\begin{array}{l}\text { HSD } \\
\alpha \\
0,05\end{array}$} \\
\hline & 30 & 60 & 90 & 120 & & \\
\hline Red onion extract & 0,92 & 0,56 & 0,46 & 0,47 & $0,60 \mathrm{~b}$ & \multirow{4}{*}{0,19} \\
\hline Atonic & 1,06 & 0,90 & 0,58 & 0,68 & $0,81 \mathrm{a}$ & \\
\hline Rata-rata & $0,99 \mathrm{a}$ & $0,73 \mathrm{ab}$ & $0,52 \mathrm{~b}$ & $0,57 \mathrm{~b}$ & & \\
\hline HSD $\propto 0,05$ & \multicolumn{5}{|c|}{0,36} & \\
\hline
\end{tabular}

Description : The average number in the column followed by the same letter was not significantly different from the HSD $\alpha 0.05$ test.

Table 5. The average of water content of Shallot tuber of treatment type of plant regulator substance .

\begin{tabular}{cc}
\hline Type of Plant Regulator Substance & Shallot Water content (\%) \\
\hline Shallot Extract & $89,49 \mathrm{a}$ \\
Atonic & $86,83 \mathrm{~b}$ \\
\hline HSD $\alpha 0,05$ & 2,25 \\
\hline
\end{tabular}

Description : The average number in the column followed by the same letter was not significantly different from the HSD $\alpha 0.05$ test

Tuber Dry Weight. The interaction of type and duration of immersion of growth regulator substance did not significantly influence dry weight of the tuber, but the single factor of the type of growth regulator and the immersion time of the growth regulator of each had a significant effect on the dry weight of the "lembah palu" shallot '. Given PGR of shallot extract resulted in higher dry weight of shallot tuber $(0.29 \mathrm{~g})$ and significantly different from atonic PGR (Table 3). Furthermore, the highest dry weight of tubers per shallot clump $(0.99 \mathrm{~g} /$ plant) with PGR immersion for 30 minutes and significantly different from the immersion times of 90 and 120 minutes, but not significantly different from the 60 minutes immersion time (Table 4). It was because the extracts of red onion tuber was believed to contain the auxin hormone because at the top of the disc which was an imperfect stem layers will be formed due to swelling because of enveloping petals, while on the inside of the bulb there are shoots that can grow into new plants (Wibowo, 1988); while atonic which had almost the same function as phytohormone containing active ingredient sodium dinonrofrofen 2,4 dinitrophenol, IBA $(0,057 \%)$ and sodium 5 nitrogulacol which can increase plant growth. Immersion tuber in PGR was found to be better at 30-60 minutes immersion compared to immersion in a longer time ie 90-120 minutes. This is because the immersion in a longer period of time will increase the number of hormones that enter into the tuber, so that the concentration becomes higher and acts to inhibit the process of cell division and plant growth. Atonic is quickly absorbed by cell and accelerates germination and rooting, but if the concentration is excessive it can inhibit growth, even though the chemical compounds contained in atonic are very useful for stimulating all parts of the plant (Kusumo, 1990).

Total Dry Weight. The interaction of type and duration of immersion of growth regulator substance did not significantly affect the dry weight of the tuber, but the type of growth regulator substance and the immersion time of growth regulator substance significantly affected the total dry weight per 'lembah palu' shallot. Given 
atonic PGR produced a higher total dry weight per shallot plant $(0.81 \mathrm{~g})$ and significantly different from PGR shallot extract (Table 4). Furthermore, the highest total dry weight per shallot clump (0.99 g / plant) with PGR immersion for 30 minutes and significantly different from the immersion time of 90 and 120 minutes, but not significantly different from the 60 minutes immersion time (Table 4). It was because atonic compound was easily absorbed into plant tissues and accelerates the flow of plasma in cell which results in all plant cells, so that it turned the plant's root physiology process took place well, vegetative and generative plant parts will grow faster and stronger (Kusumo, 1990). In addition to accelerate cell elongation that causes elongation of the stem and roots, the role of other auxin is the combination of auxin and giberelin in PGR in shallot and atonic extracts which will stimulate the development of vascular tissue and encourage cell division in vessel cambium thus supporting the formation of stem diameter, durationening plant segments and enlarge leaf area (Rusmin, 2011).

Tuber water contenct. The interaction of type and duration of immersion of growth regulator substance and single factor of PGR immersion time did not significantly affect the moisture content of the tubers, but the type of growth regulator substance significantly affected the moisture content of the 'lembah palu' shallot tuber. Addition of PGR shallot extract resulted in higher shallot tuber moisture content $(89.49 \%)$ and significantly different from atonic PGR $(86.83 \%)$ (Table 5). It was because natural onion extract allowed for more absorbed tubers to increase the moisture content of tubers to activate auxin and giberellin growth hormones found in tubers so that they can stimulate the germination of shallot bulbs. Longer immersion can allow the seed to encounter higher inbibration, so that the water content of the seed after immersion will increase and stimulate germination.

\section{CONCLUSION}

The results showed that (i) shallot soaked with $100 \mathrm{~g} /$ iter of shallot extract for $30-90$ minutes produced $100 \%$ germination power, and tubers soaked of shallot for 30 minutes produced germination rates of $31.3 \% / e t m a l$, (ii) the type of growth regulator for shallot extract and atonic effect was not significant for onion germination; and (iii) the duration of PGR for 30 minutes immersion results in the highest hypothetical vigor index.

\section{REFERENCES}

Abidin, Z. 1990. Dasar-Dasar Pengetahuan tentang Zat Pengatur Tumbuh. Bandung: Penerbit Angkasa.

Erlianti. 1999. Pengujian Aktivitas Antiagregase Platelet dari Senyawa Hasil Hidrolisis Komponen Prekursor Flavor Bawang-bawangan oleh Enzim Allinase dan Senyawa Sintetis Turunan Vinildhitin. Skripsi tidak dipublikasikan. FTP, Institut Pertanian Bogor.

Gomez, K.A. and A.A.Gomez. 1995. Prosedure statistik untuk penelitian pertanian. Terjemahan Endang Syamsuddin dan Justika S Baharsjah. Edisi kedua. UI-Press. Jakarta.

Hartmann, H.T., D.E. Kester, F. T. Davies, dan R. L. Geneve. 1997. PlantPropagation (6th Edition). Upper Saddle River. New Jersey. 770 pp.

Heddy, S. 1989. Hormon Tumbuhan.Jakarta: CV. Rajawali.

Kusumo, S. 1990. Zat Pengatur Tumbuh Tanaman. Bogor: Cv. Jasaguna 
Marfirani, M., Y. S. Rahayu, dan E. Ratnasari. 2014. Pengaruh pemberian berbagai konsentrasi filtrat umbi bawang merah dan Rootone-F terhadap pertumbuhan stek melati rato ebu. Jurnal LenteraBio 3(1): 73-76.

Masna, 2017. Pengaruh Ukuran Berat Umbi dan Atonik Terhadap Pertumbuhan dan hasil Bawang Merah Varietas Lembah Palu (Allium Cepa L.). Tesis. Pascasarjana Universitas Tadulako. Palu.

Mayasari, E; L.S. Budipramana, dan Y.S Rahayu, 2012. Pengaruh Pemberian Filtrat Bawang Merah dengan Berbagai Konsentrasi dan Rootone-F terhadap Pertumbuhan Stek Batang Tanaman Jambu Biji (Psidium guajava L). LenteraBio Vol. 1 No. 2 Mei 2012: 99-103.

Muhammad-Ansar, Bahrudin dan I. Wahyudi, 2015.Pengaruh Umur Panen dan Lama Penyimpanan Terhadap Viabilitas dan Vigor Benih Bawang Merah 'Lembah Palu'. Prosiding Seminar Nasional Perhorti. 19-21 Nopember 2015, di IPB Bogor.

Muhammad-Anshar, Bahrudin dan I. Wahyudi, 2016.Aplikasi Zat Pengatur Tumbuh Untuk Meningkatkan Pertumbuhan dan Hasil Umbi Bawang Merah Varietas Lembah Palu. Prosiding Seminar Nasional Perhorti. 14 Nopember 2016 di Universitas Hasanuddin. Makasar.

Pasigai, M.A, A.R. Thaha, B. Nasir, A.A. Lasmini, Maemunah dan Bahrudin, 2016. Teknologi Budidaya Bawang Merah Varietas Lembah Palu. Edisi Pertama. Untad Press. Palu.

Rusmin, D. 2011. Pengaruh Pemberian GA Pada Berbagai Konsentrasi dan Lama Inbibisi Terhadap Peningkatan Viabilitas Benis Puwoceng (Pimpinella pruatjan Molk.). Jurnal Littri. Vol: 17. No: 3

Salisbury, F.B. dan C.V. Ross. 1995. Fisiologi Tumbuhan Jilid 3. ITB Press. Bandung.

Sasmitamihardja, D dan Siregar, A. 1996. Fisiologi Tumbuhan. Institut Teknologi Bandung. Bandung.

Siswanto. U. 2010. Penggunaan Auksin dan Sitokinin Alami Pada Pertumbuhan Bibit Lada Panjang (Piper retrofractum vah L.). Jurnal Tumbuhan Obat Indonesia Vol. 3 No. 2.

Wibowo, S. 1988. Budidaya Bawang: Bawang Putih, bawang Merah, dan Bawang Bombay. Penebar Swadaya. Jakarta. $201 \mathrm{hlm}$.

\section{ACKNOWLEDGEMENT}

Thank you to the Directorate of Research and Community Service. Directorate General of Research and Development. Ministry of Research, Technology and Higher Education for research facilities in the 2017 Fiscal Applied Research Research scheme. 